\title{
NAHDLATUL ULAMA DI LUAR JAWA: Perkembangan di Tanah Mandailing
}

\author{
Abbas Pulungan \\ Universitas Islam Negeri Sumatera Utara Medan \\ Jl. Willem Iskandar Pasar V Medan Estate, Medan, Sumatera Utara, 20371 \\ e-mail: abbaspulungan@uinsu.ac.id
}

\begin{abstract}
Nahdlatul Ulama Beyond Java: The Development in Mandailing Land. This article examines the development of Nahdhatul Ulama beyond Java, especially in Mandailing land. This article is based on a research that combine literary review and field study and apply Miles and Huberman model in data analysis. It was found that the establishment of Nahdlatul Ulama in North Sumatra was initiated by alumnies of Pesantren Musthafawiyah, a traditional pesantren founded by Syekh Musthafa Husein. The role of these pesantren alumnies-mostly of Mandailing tribe-is now decreasing significantly. In fact, the leadership of Nahdlatul Ulama in North Sumatra is no longer in the hands of those santris. Nahdlatul Ulama in North Sumatra was originated from Tapanuli region before it expanded to Medan where two other Islamic organizations have appeared earlier, namely Al Washliyah and Al-Ittihadiyah. Its development was further strengthened by the presence of NU cadres in the government bureaucracy and legislative institutions.
\end{abstract}

Keywords: Nahdlatul Ulama, politic, Mandailing, Pesantren Musthafawiyah 


\section{Pendahuluan}

Nahdlatul Ulama, disingkat NU, diklaim sebagai organisasi Islam terbesar di Indonesia yang telah memberikan kontribusi bagi agama dan negara. ${ }^{1}$ Organisasi ini seakan menjadi teks yang kaya nuansa dan kaya warna. Banyak orang yang menafsirkan, menganalisis, dan membaca ulang NU seakan tiada habis-habisnya. Di antaranya, ada yang memuji dan ada yang mengecam, atau ada yang melihatnya dengan jernih dan objektif, yakni menampilkan kelebihan dan kekurangan NU sekaligus. Sejak tahun 1980-an sampai sekarang, telah banyak kajian dan literatur yang terbit menghiasi kepustakaan tentang NU. Nampaknya, kajian tentang organisasi NU jauh melampaui kajian organisasi Islam lainnya, termasuk Muhammadiyah sekalipun. Jika dicermati, ternyata citra NU yang konservatif, oportunis, dogmatis, dan stigma-stigma negatif lainnya, tidak sepenuhnya benar. Sebagai organisasi Islam, ternyata wajah NU sedemikian kompleks, beragam dan penuh nuansa. Bahkan ada gerak dinamika yang saling berlawanan dan bertabrakan dalam tubuh NU. Justru karena ada tesa dan antitesa dalam tubuh organisasi ini, NU bergerak terus dalam irama yang dinamis.

Dalam rentang kurun waktu 1926-1990-an, setidaknya NU hidup dalam masa tiga rezim, yakni rezim imperialis (Belanda, Jepang, dan Inggris), rezim Orde Lama (Soekarno), dan rezim Orde Baru (Soeharto). Pada kurun waktu 1926-1942 (zaman kolonial Belanda), NU abstain dari dunia politik. Kemudian tahun 1942-1945 di masa pendudukan Jepang, NU mulai berpolitik. Pada tahun 1952-1959 (era Demokrasi Terpimpin), NU berubah bentuk dari organisasi keagamaan menjadi organisasi politik. Di masa Demokrasi Terpimpin Soekarno tahun 1959-1965, NU menjadi salah satu pendukung rezim Soekarno. ${ }^{2}$ Dalam masa ini, NU mengalami dilema-dilema yang sangat pelik. Kemudian tahun 1966 hingga pertengahan tahun 1990-an, NU hidup dalam era rezim Soeharto (Orde Baru). 
Pada awal berdirinya, NU sebenarnya hanya dimaksudkan sebagai organisasi keagamaan yang menangani persoalan-persoalan kemasyarakatan, tetapi dalam perjalanannya NU pernah benarbenar larut dalam arena politik, misalnya ketika bergabung dalam Partai Masyumi atau ketika melepaskan diri dari Masyumi lantas menjadi partai politik tersendiri. ${ }^{3}$ Ketika menjadi partai politik, NU benar-benar larut dalam gelanggang politik praktis. Ketika jenuh dalam pusaran politik praktis, tugas-tugas sosial kemasyarakatan NU agak terbengkalai. Belajar dari kondisi seperti ini, pada tahun 1984, NU kemudian bertekad untuk kembali ke Khittah 1926, yakni mengembalikan fungsi NU sebagai organisasi sosialkemasyarakatan, bukan partai politik dan bukan berpolitik (praktis). ${ }^{4}$

Dari uraian di atas, NU merupakan organisasi berskala nasional. Tetapi, organisasi ini tidak hanya berkembang di Pulau Jawa, khususnya di Jawa Timur dan Jawa Tengah saja. Organisasi NU telah berdiri dan berkembang di berbagai wilayah Indonesia pada kurun waktu satu atau dua dasawarsa setelah berdiri tahun 1926. ${ }^{5}$ Di Sumatera Utara misalnya, Nahdlatul Ulama berdiri setelah Indonesia merdeka, yakni tahun 1947 di Padangsidimpuan Tapanuli Selatan, yang dideklarasikan pada saat berlangsung Kongres Kaum Muslimin se-Tapanuli tanggal 7-9 Februari 1947. Pada dasarnya, organisasi NU mempunyai kesamaan pada asas, tujuan, dan paham keislaman Ahlussunnahwaljamaah (Aswaja) dan berpegang teguh pada salah satu mazhab yang empat, ${ }^{6}$ namun perilaku berorganisasi, keberagamaan, dan orientasi politiknya bisa terdapat kelainan, karena terdapat perbedaan kultur para pemimpin dan jamaahnya serta latar belakang sejarah yang mengitarinya.

Kehadiran organisasi NU di Sumatera Utara pada tahun 1947 adalah karena adanya respons terhadap berkembangnya paham keislaman yang bertolak belakang dari pemahaman sebagian besar ulama di daerah Tapanuli, katakan saja "paham modernis" 
yang dikembangkan oleh Muhammadiyah melalui Partai Masyumi. Sebelum berdiri organisasi Muhammadiyah ${ }^{7}$ dan Partai Masyumi, telah berdiri lebih dahulu Sarekat Islam (SI) tahun 1927 dan organisasi Al Jam'iyatul Washliyah tahun 1930. ${ }^{8}$ Para pendiri NU tahun 1947 tersebut, sebagian telah masuk dalam organisasi keislaman sebelumnya, seperti Syekh Musthafa Husein dari Pesantren Musthafawiyah Purbabaru Mandailing. Ia pernah menjadi Dewan Penasihat dalam Sarekat Islam (SI), Al Washliyah dan Partai Masyumi. Hal demikian, kemungkinan mempunyai persamaan dengan pengalaman sebagian ulama/kiai pendiri Nahdlatul Ulama tahun 1926, semisal KH. Hasyim Asy'ari. ${ }^{9}$ Dalam perjalanan organisasi NU di Sumatera Utara, tampaknya belum banyak terungkap atau ditulis secara komprehensif, berbeda dengan Nahdlatul Ulama secara nasional yang sudah mencapai puluhan tahun menghiasi kepustakaan.

Cukup menarik untuk mengkaji organisasi keislaman di Sumatera Utara. Pertama, Al Jam'iyatul Washliyah berdiri tahun 1930 di Medan adalah sebagai cikal-bakal atau dimulai dari Maktab Islamiyah Tapanuli (MIT) di Medan, yang umumnya adalah tokoh dan ulama etnis Mandailing yang migrasi ke Tanah Deli, Sumatera Timur. ${ }^{10}$ Kedua, Muhammadiyah berdiri di Sumatera Timur sekitar tahun 1928, umumnya dikembangkan oleh etnis Minangkabau juga sebagai migran di daerah Deli Sumatera Timur. ${ }^{11}$ Ketiga, Al-Ittihadiyah adalah organisasi yang bermula dari Madrasah Mahmudiyah di LangkatSumatera Timur dan didirikan oleh etnis Melayu tahun 1935-an. ${ }^{12}$ Keempat, Nahdlatul Ulama pertama kali berdiri di Padangsidimpuan tahun 1947, para pendirinya adalah etnis Mandailing, dan berbasis di Pesantren Musthafawiyah Purbabaru Mandailing. ${ }^{13}$ Organisasi NU berasal dari organisasi lokal yang didirikan oleh Syekh Musthafa Husein dengan nama Al-Ittihadul Islamiyah (AII) tahun 1935, kemudian dilebur menjadi organisasi Nahdlatul Ulama. Pada tahun 1952/53, organisasi NU ini dipindahkan ke Medan sebagai ibukota Propinsi Sumatera 
Utara setelah terbentuk Negara Kesatuan Republik Indonesia (NKRI) Agustus 1950, kemudian berkembang di kalangan masyarakat (etnis) Melayu di Sumatera Timur. Dengan demikian, dalam perjalanannya, organisasi ini menjadi perpaduan antara keberagamaan etnis Mandailing dengan etnis Melayu Sumatera Timur.

Pada waktu berdiri organisasi, Nahdlatul Ulama (NU) di kawasan ini, Sumatera Utara belum menjadi provinsi tersendiri. Berdirinya provinsi ini setelah berakhirnya "Revolusi Sosial' di Sumatera Timur, kemudian terjadi kesepakatan politik antara Keresidenan Sumatera Timur dengan Keresidenan Tapanuli masuk ke dalam Negara Kesatuan Republik Indonesia (NKRI) pada bulan Agustus 1950. Ketidakstabilan sosial di Sumatera Timur sejak tahun 1946 sebagai awal gerakan sosial dan puncaknya tahun 1947-1948. Pada akhir tahun 1948, agresi militer Belanda ke-2 telah menguasai kota-kota penting di Sumatera Timur. Kelompok bangsawan Sumatera Timur sebenarnya sejak tahun 1946 tidak banyak menaruh simpati terhadap Republik Indonesia. Setelah terjadi "Revolusi Sosial” tersebut, kelompok ini mendambakan supaya kolonial Belanda kembali menguasai wilayah ini. Puncak dari kelompok oposisi terhadap RI adalah dengan dideklarasikannya Negara Sumatera Timur (NST) pada bulan Juli 1948 dan berlangsung hingga Agustus 1950. ${ }^{14}$

Situasi sosial yang cukup menegangkan di Sumatera Timur ini banyak melibatkan etnis dan suku bangsa yang di masa kolonial Belanda merasa dirugikan. Hal ini sebenarnya telah berlangsung sejak tahun 1920-an setelah di Sumatera Timur dibuka perkebunan secara besar-besaran oleh pemerintah kolonial Belanda. Di daerah Keresidenan Tapanuli yang berpusat di Sibolga, situasi sosial relatif lebih aman dan tertib. Hal ini menjadi salah satu faktor bagi etnis Mandailing yang telah menganut agama Islam mendirikan gerakan-gerakan sosial keagamaan melalui organisasi Islam, seperti organisasi AI Washliyah yang berpusat di 
Medan (1930), dan Nahdlatul Ulama yang berdiri di Padangsidimpuan (1947).

\section{Awal Berdiri NU di Sumatera Utara Kongres Kaum Muslimin se-Tapanuli}

Organisasi Nahdlatul Ulama (NU) di Sumatera Utara berdiri setelah Indonesia merdeka, yaitu pada tahun 1947 di Padangsidimpuan Tapanuli Selatan. Proses pendirian organisasi ini disponsori oleh para lulusan Madrasah Musthafawiyah Purbabaru dan didukung sepenuhnya oleh Syekh Musthafa Husein sebagai ulama terkemuka pada waktu itu. Sebelum berdirinya NU di daerah ini, telah berdiri organisasi-organisasi Islam seperti Al Jam'iyatul Washliyah, Sarekat Islam (SI), Muhammadiyah dan Al-Ittihadiyah Islamiyah Indonesia (AII) yang berpusat di Purbabaru. AII adalah organisasi yang bersifat lokal dan lebih tepat dinamakan semacam perkumpulan, karena anggotanya hanya para lulusan dan murid Madrasah Musthafawiyah. Pada waktu NU didirikan, Al-Ittihadiyah Islamiyah Indonesia dilebur ke dalam Nahdlatul Ulama, begitu juga sebagian kecil tokoh Al Washliyah.

Proses berdirinya NU di Sumatera Utara dimulai dari pemikiran untuk melaksanakan tabligh akbardi Panyabungan sebagai pernyataan dan syukuran atas kemerdekaan Indonesia tanggal 17 Agustus 1945. Atas prakarsa sejumlah tokoh, di antaranya M. Nuddin Lubis, dari pemuda Islam yang umumnya adalah lulusan Madrasah Musthafawiyah, dan kegiatan ini dilakukan setelah mendapat persetujuan dari Syekh Musthafa Husein Purbabaru dan ulama lainnya di Mandailing, di antaranya Syekh Ja'far Abdul Kadir. Tabligh akbarini dilakukan pada tahun 1946 bertempat di Madrasah Mardiyah Islamiyah (MMI) Panyabungan (Madrasah yang dibangun dan diasuh Syekh Ja'far Abdul Kadir berdiri tahun 1935). Hasil dari tabligh akbar ini diambil keputusan untuk melaksanakan 
Kongres Kaum Muslimin se-Tapanuli pada tahun 1947 di Padangsidimpuan. Kongres ini berlangsung tanggal 7-9 Februari 1947 bertempat di Madrasah Islamiyah Padangsidimpuan yang dihadiri oleh pemuka-pemuka agama Islam, ulama dan pemuda Islam dari berbagai pelosok di Tapanuli, seperti perwakilan dari Mandailing, Padang Lawas, Angkola-Sipirok, Natal, dan Sibolga.

Kongres Kaum Muslimin se-Tapanuli ini telah menghasilkan beberapa keputusan. Pertama, para ulama yang berpaham Ahlussunnahwaljamaah sependapat untuk membentuk organisasi Islam yang bersifat nasional dengan nama Nahdlatul Ulama (NU). Kedua, organisasi yang bersifat lokal seperti Al-Ittihadiyah 1slamiyah (AII) dilebur menjadi Nahdlatul Ulama (NU), dan ada empat cabang AI Jam'iyatul Washliyah di Tapanuli Selatan bergabung dengan NU atas permintaannya sendiri. Ketiga, untuk sementara sebelum mendapatkan Anggaran Dasar dan Anggaran Rumah Tangga (AD \& ART) NU dari Pengurus Besar, telah dibuat AD \& ART sementara yang banyak mengacu kepada AD \& ART AII sebelumnya. Keempat, kongres menetapkan tiga orang formatur untuk menyusun kepengurusan, yaitu Haji Baharuddin Thalib Lubis, Haji Dja'far Abdul Wahab, dan Muhammad Amin Awwal. Adapun susunan pengurus sebagai berikut:

Penasihat :Syekh Musthafa Husein(Purbabaru, Mandailing)

Ketua Umum : H. Baharuddin Thalib Lubis (Sibolga)

Ketua I : M. Nuddin Lubis (Musthafawiyah)

Ketua II : Muhammad Amin Awwal (Sibolga)

Setia Usaha I : Aminuddin Aziz (Musthafawiyah)

Setia Usaha II : Alauddin Panggabean (Sibolga)

Bahagian-bahagian terdiri atas:

Pendidikan : M. Amin Awwal

Penerangan : M. Nuddin Lubis 
Fatwa : Syekh Dja'far Abdul Ahab (Musthafawiyah)

Perencanaan: Sai Aman Nasution (Musthafawiyah)

Pembantu : Ali Husin Samin Siregar (Angkola)

Syahrum Alam, Siti Amas

Kelima, hasil keputusan kongres ini dilaporkan kepada Pengurus Besar NU di Jawa dan meminta pengesahannya, dan untuk sementara organisasi ini berkedudukan di Sibolga sebagai ibukota Keresidenan.

Selain keputusan kongres di atas, kongres ini juga telah mengambil langkah-langkah untuk membangun organisasi dengan menghimbau kepada seluruh peserta kongres untuk mendirikan Nahdlatul Ulama di daerah masing-masing, mengupayakan agar semua organisasi dan perkumpulan umat Islam yang telah berdiri di daerah Tapanuli dilebur menjadi organisasi Nahdlatul Ulama. Kongres ini juga memutuskan untuk pembiayaan organisasi diambil dari peserta kongres yang dibagi kepada per daerah (Kewedanaan) dan ditetapkan petugas sebagai penanggung jawabnya. Untuk wilayah Mandailing, penanggung jawabnya adalah Syekh Musthafa Husein Purbabaru, untuk wilayah Padang Lawas adalah Zubir di Gunung Tua dan dibantu oleh dua orang yakni $M$. Basyir dan Haji Idris Zk., untuk wilayah Angkola-Sipirok oleh Haji Maksl dan Malim Bandaharo, untuk wilayah Natal adalah Haji M. Zain Sipagu Batang Natal, dan untuk wilayah Sibolga adalah $\mathrm{H}$. Baharuddin Thalib Lubis. Uang untuk modal pertama, organisasi ini berjumlah Rp. 50.000,00 (Limapuluhribu Rupiah) dan diserahkan kepada pimpinan organisasi.

Menyangkut dengan penataan dan kehidupan umat Islam di Tapanuli, kongres memutuskan untuk mendirikan dan menghidupkan kembali madrasah dan lembaga-lembaga pendidikan Islam di setiap daerah. Kongres juga menyoroti tentang kedudukan Dewan Agama Islam di Tapanuli. Menurut pendapat mereka bahwa 
personalia/pejabat di Jawatan Agama tidak sesuai dengan bunyi instruksi Pejabat Agama Sumatera, karena didominasi oleh sekelompok kecil golongan dan tidak mencerminkan golongan mayoritas umat Islam Tapanuli di mana 80\%-nya adalah penganut Ahlussunnahwaljamaah. Melihat realita ini, Kongres Kaum Muslimin se-Tapanuli membuat semacam resolusi dan mosi tidak percaya kepada Pejabat Agama Islam Tapanuli saat itu. Resolusi ini disampaikan kepada Residen Tapanuli di Sibolga, dan salinannya disampaikan kepada Gubernur Sumatera dan Menteri Agama di Yogyakarta. Dasar pemikiran lahirnya resolusi pertama yang dikeluarkan Nahdlatul Ulama wilayah Tapanuli ini adalah karena Pejabat Agama Islam di Tapanuli didominasi oleh paham Islam yang bukan Ahlussunnahwaljamaah dan memberlakukan paham sepihak saja yang bernaung dalam Partai Masyumi. Melihat penetapan hukum dan kebijakan yang diambil oleh Pejabat Agama Islam Tapanuli akan berimbas kepada perpecahan umat Islam, di dalam isi resolusi yang dikeluarkan terlihat cukup keras, karena termuat di antaranya "jika tuntutan mereka tidak diindahkan," maka organisasi Nahdlatul Ulama Tapanuli bersikap pasif dan tidak ikut bertanggung jawab atas eksistensi Jawatan Agama Islam Tapanuli.

\section{Konferensi Pertama}

Pada tahun 1950, dilakukan konferensi pertama Nahdlatul Ulama Tapanuli di Padangsidimpuan tanggal 8-10 September 1950. Konferensi diikuti oleh seluruh pengurus daerah di setiap kecamatan se-Tapanuli. Konferensi ini langsung dihadiri oleh Pengurus Besar Nahdlatul Ulama yang berkedudukan di Surabaya pada waktu itu. Pengurus Besar yang hadir adalah KH. Masykur, KH. Saifuddin Zuhri, dan KH. Zainal Arifin. Konferensi Nahdlatul Ulama (NU) Tapanuli pertama ini telah mengacu kepada Anggaran Dasar dan Anggaran Rumah Tangga Nahdlatul Ulama, seperti struktur organisasi dan sekaligus pembentukan organisasi otonom 
seperti Muslimat, Fatayat, dan Gerakan Pemuda Ansor. Selain itu, kepengurusan NU wilayah Tapanuli ditetapkan dan disahkan oleh Pengurus Besar menjadi Konsulat Nahdlatul Ulama wilayah Sumatera Utara berkedudukan di Padangsidimpuan. Khusus untuk wilayah Medan sebagai ibukota Propinsi Sumatera Utara ditetapkan Komisaris untuk Medan. Adapun susunan personalia Pengurus Wilayah Sumatera Utara sebagai berikut:

Rais Syuriyah : :Syekh Musthafa Husein(Musthafawiyah Purbabaru)

Wakil Rais Syuriyah : Haji Muchtar Siddiq (Musthafawiyah Purbabaru)

Konsul

Wakil Konsul

: Haji Baharuddin Thalib Lubis (Sibolga)

Ketua Harian

:Syekh Ali Hasan ad-Dary (Musthafawiyah)

Sekretaris

: M. Nuddin Lubis (Musthafawiyah)

: Haji Abdul Djabbar Nasution

(Musthafawiyah)

Bendahara

: Haji Muhammad Saleh

Bahagian-bahagian:

Urusan Umum

:Sai Aman Nasution (Musthafawiyah)

Komisaris Medan

: Aminuddin Aziz Pulungan

Ma'arif

:SyekhDjałfar Abdul Wahab(Musthafawiyah)

Dakwah

: Ali Husin Samin Siregar

Sosial

: Haji Ismail Sulaiman (Musthafawiyah)

Muslimat

: Esya Tanjung

Kepentingan NU wilayah Sumatera Utara di atas masih didominasi oleh lulusan Madrasah Musthafawiyah yang berdomisili di Tapanuli Selatan dan Tapanuli Tengah (Sibolga). Dari segi etnis, belum terlihat keragamannya, karena kepengurusan NU 
ini masih dalam lingkup Tapanuli. Berbeda halnya setelah kepengurusan wilayah pindah ke Medan sebagai ibukota Provinsi Sumatera Utara, di mana etnis Melayu Sumatera Timur akan masuk dalam kepengurusan. Program yang dilakukan lebih berorientasi kepada pembentukan dan pendirian organisasi di tingkat kecamatan dan pedesaan. Jalur yang dipakai adalah melalui ceramah-ceramah dan pengajian yang dilakukan oleh pemuka agama Islam setempat atau sengaja dihadirkan dari pengurus/pimpinan organisasi.

\section{Konferensi Kedua}

Pada tahun 1953 dilakukan Konferensi Wilayah kedua yang merupakan gabungan Konsulat NU wilayah Sumatera Utara di Padangsidimpuan dengan Perwakilan Konsulat NU Sumatera Utara di Medan. Sebelum berlangsung konferensi, terlebih dahulu dilakukan penyempurnaan kepengurusan wilayah Sumatera Utara dengan memasukkan wajah-wajah baru, terutama dari etnis Melayu Sumatera Timur. Di antara mereka itu ialah Tengku H. Yafizham, dan Syekh Abdullah Afifuddin dari Langkat. Penyusunan kepengurusan baru ini berlangsung pada tanggal 4-5 Januari 1953 di Medan, dan dihadiri utusan Pengurus Pusat NU oleh Haji Zainal Arifin.

Sebagai realisasi pertemuan di atas, pada tanggal 24-26 Oktober 1953 dilaksanakan konferensi kedua Nahdlatul Ulama wilayah Sumatera Utara di Medan, dan dihadiri langsung oleh Pengurus Besar NU yang terdiri atas KH. Wahab Hasbullah dan H. Zainul Arifin. Berikut hasil keputusan konferensi. Pertama, mensosialisasikan keputusan Muktamar NU di Palembang tahun 1952, bahwa Nahdlatul Ulama telah menarik diri atau keluar dari Partai Masyumi dan sekaligus menyatakan sebagai Partai Nahdlatul Ulama. Kedua, memindahkan sekretariat wilayah NU Sumatera Utara dari Sibolga ke Medan sebagai ibukota Propinsi Sumatera Utara. Ketiga, menyusun personalia kepengurusan wilayah Nahdlatul Ulama Sumatera Utara periode 1953-1956, dan disesuaikan dengan 
struktur organisasi yang terdapat pada Anggaran Dasar dan Anggaran Rumah Tangga (AD \& ART NU). Adapun susunan kepengurusan Nahdlatul Ulama Sumatera Utara sebagai berikut:

Syuriah:

Rais Syuriah :Syekh Musthafa Husein(Purbabaru/Mandailing)

Naib Rais I : Syekh Abdullah Afifuddin (Langkat/Melayu)

Naib Rais II : KH. Abdul Madjid

Katib I : Zakaria Abdul Wahab

Katib II : Samin Ibrahim

A'wan : Syekh Dja'far Abdul Kadir

Haji Muhammad Thahir

Haji Abdurrahman Djabbar

Konsulat :

Konsul : H. Baharuddin Thalib Lubis

Wakil Konsul : M. Nuddin Lubis

Sekretaris : H. Abdul Djabbar Nasution

Bendahara : Tengku H. Jafizham

Bidang-Bidang :

Bidang Dakwah : Ali Husin Samin Siregar

Bidang Mabarrot : Abir Zuhdi Daulay

Bidang Ekonomi : Muhammad Karim

Bidang Ma'arif : H. Abdurrahman Djabbar Nasution

Pembantu : Sai Aman Nasution, Alinafiah Lubis

Pada periode kepengurusan 1953-1956, Nahdlatul Ulama telah menjadi partai politik dan tidak lagi sebagai organisasi sosial-keagamaan. Orientasi kegiatannya semakin kompleks, dalam arti telah masuk ke dalam politik praktis dalam tatanan kehidupan 
bangsa dan negara. Pada tahun 1954, untuk persiapan menghadapi Pemilihan Umum pertama tahun 1955, kepengurusan wilayah mengalami pergeseran dan penambahan struktur oraganisasi, yaitu bidang Ma'arif dijabat oleh Tengku $\mathrm{H}$. Jafizham (sebelumnya Bendahara) dan untuk posisi Bendahara dijabat oleh Ali Hanafiah Lubis (sebelumnya sebagai Pembantu), Lajnah Pemilihan Umum Nahdlatul Ulama (Lapunu) dijabat oleh Sai Aman Nasution (sebelumnya sebagai Pembantu), dan Haji Abdurrahman Djabbar Nasution menjadi Pembantu (sebelumnya sebagai Ma'arif).

Sebagai konsekuensi organisatoris setelah Nahdlatul Ulama menjadi partai politik yang diputuskan oleh Muktamar NU di Palembang tahun $1952,{ }^{15}$ seluruh pengurus NU mulai dari wilayah sampai ke kabupaten, kecamatan, dan tingkat desa ikutserta mensukseskan pemenangan partai ini pada Pemilu 1955. Posisi ulama sebagai pemimpin dan panutan masyarakat semakin diperlukan untuk mensosialisasikan dan memperkenalkan organisasi NU kepada masyarakat luas. Hal ini terlihat dengan jelas bagaimana para ulama NU melakukan himbauan sampai kepada membuat fatwa disampaikan pada berbagai kesempatan, termasuk pada saat berlangsung kampanye Pemilu di hadapan masyarakat secara terbuka. Seruan dan fatwa tersebut disampaikan oleh Syekh Musthafa Husein Purbabaru, Syekh Abdullah Afifuddin Langkat, dan Syekh Abdurrahman Abdul Djabbar.

\section{Pengembangan Aswaja}

Seruan ajakan dan fatwa ulama Nahdlatul Ulama Sumatera Utara yang disampaikan pada waktu menjelang Pemilihan Umum tahun 1955 pada intinya menyerukan kepada seluruh umat Islam agar memilih dan masuk dalam partai yang berpaham Ahlussunnahwaljamaah, yang secara kebetulan Partai Nahdlatul Ulama adalah satu-satunya partai Islam yang berpaham tersebut. Hal ini terlihat dalam seruan Syekh Musthafa Husein yang 
ditujukan kepada para guru agama, pemimpin Islam, dan semua murid-muridnya, yang dibuat di Purbabaru pada tanggal 18Zulqa'idah 1374 H. bersamaan dengan 8 Juli 1955. Selanjutnya Syekh Musthafa Husein membuat amanat tertulis menjelang Pemilu 1955 yang ditandatangani bersama dengan Syekh Dja'far Abdul Kadir dan Syekh Ja'cub Abdul Kadir Panyabungan. Amanat tertulis ini terdiri atas lima poin, dan poin kelima terdiri atas tiga ayat, di mana pada ayat ke satu berbunyi "(a) peliharalah agamamu, i'tikadmu dan pahammu dengan tjara memperdjuangkan kemenangan partai yang mempertahankan i’tikad Ahlussunnah wal djama'ah dan mazhab jang empat.” Amanat ini dibuat di Purbabaru pada tanggal 24 September 1955 sekitar satu setengah bulan sebelum ia wafat tanggal 16 November 1955.

Senada dengan seruan dan amanat tertulis di atas, Syekh Abdullah Afifuddin Langkat membuat seruan tertulis yang ditujukan kepada seluruh kaum Muslim, terutama kepada anggota keluarga dan murid-muridnya untuk memilih partai Islam yang berhaluan Ahlussunnahwaljamaah. Di antara teks seruannya itu ialah "marilah kita sama-sama memilih tanda gambar NU untuk memperdjuangkan agama Allah, mazhab Ahlussunnahwaljamaah serta bertaqlid pada salah satu Imam jang empat." Seruan ini dibuat ia pada tanggal 6 Oktober 1955, dan pada waktu itu ia adalah Wakil Rais Syuriah NU wilayah Sumatera Utara bersama Syekh Musthafa Husein sebagai Rais Syuriah.

Seruan selanjutnya disampaikan oleh Syekh Abdurrahman Abdul Djabbar yang menjabat pada waktu itu sebagai anggota Syuriah NU wilayah Sumatera Utara, mengajak kaum Muslim memilih dan masuk ke dalam arti Islam yang berpaham Ahlussunnahwaljamaah. Seruannya ini disampaikan pada hari Jum'at, 19 Agustus 1955, pada saat kampanye akbar di Galang, Deli Serdang. Ia menguraikan pengertian Ahlussunnahwaljamaah itu lebih sosiologis, yaitu dalam paham Ahlussunnahwaljamaah 
tidak hanya mengurusi umat Islam yang hidup saja, tetapi setelah meninggal pun tetap diperhatikan dengan membaca talqin saat pemakaman, melakukan salat gaib berjamaah pada setiap pertengahan bulan Arab yang lazim disebut dengan lailatul ijtima'dan apabila kaum Muslim meninggal dilakukan tahlilan. Tradisi demikian inilah antara lain yang membedakan Nahdlatul Ulama dengan organisasi Islam lainnya. Selanjutnya ia menyebutkan "makan, minum, berumah tangga menurut Islam yang bermazhab, maka berdjuang dan berpartailah menurut mazhab djuga”.

Dalam organisasi Nahdlatul Ulama, kedudukan ulama sangat tinggi dan dihormati. Dalam struktur organisasi, para ulama ini ditempatkan di atas dengan jabatan Syuriah, sedangkan sebagai pelaksana operasional dilaksanakan oleh Tanfidziah dan badan-badan otonom lainnya. Posisi ulama yang tergabung dalam jabatan Syuriah mempunyai hak untuk menilai dan mengevaluasi kebijakan-kebijakan pimpinan organisasi, juga mereka ini mempunyai wewenang memberikan fatwa yang harus dipedomani seluruh jamaah Nahdlatul Ulama. Pembinaan dan pengembangan paham Ahlussunnahwaljamaah pada umumnya dilakukan para ulama sebagai panutan umat Islam.

Sarana yang paling efektif dalam pembinaan dan pengembangan organisasi Nahdlatul Ulama dan paham Ahlussunnahwaljamaah adalah melalui jalur pendidikan Islam. Akar kekuatan dan otoritas setiap ulama (kiai) dalam organisasi NU banyak dipengaruhi aktivitasnya sebagai pengaruh sebuah pesantren. ${ }^{16}$ Semakin tinggi dan besar pesantren yang dikelola dan diasuhnya, semakin besar pula penghargaan dan penghormatan diberikan kepadanya. Penghormatan itu tidak hanya diberikan oleh organisasi, tetapi juga diberikan oleh masyarakat luas. Setidaknya, realita ini dapat berlaku di Jawa, namun di luar Jawa termasuk di wilayah Sumatera Utara hal demikian tidak seluruhnya berlaku. Kemungkinan besar, hal inilah yang menjadi salah satu faktor kenapa organisasi 
Nahdlatul Ulama kurang berkembang di Sumatera Utara, khususnya daerah yang tidak memiliki lembaga pendidikan semacam pesantren.

\section{Periodesasi NU di Sumatera Utara Periode Awal Berdiri, 1947-1971}

Pembinaan dan pengembangan NU di Sumatera Utara pada awal berdirinya tahun 1947-1953 adalah dilakukan melalui jalur kultural dan struktural. Pendekatan kultural adalah melalui para ulama yang berpusat di Purbabaru Mandailing, juga keterlibatan guru-guru agama yang umumnya adalah lulusan Madrasah Musthafawiyah, dimana mereka memberikan peranan dan jasa yang besar untuk memperkenalkan dan pembentukan NU di setiap kecamatan dan desa-desa di Kabupaten Tapanuli Selatan. Pada akhirnya sampai tahun 1953, organisasi NU telah berdiri di seluruh kecamatan dan pada peresmiannya dihadiri oleh Syekh Musthafa Husein dan ulama-ulama lainnya. Hal ini berbeda dengan organisasi lain seperti Muhammadiyah yang tidak banyak melibatkan ulama di samping organisasi ini kurang mendapat sambutan dari masyarakat Tapanuli Selatan pada waktu itu, kecuali masyarakat Minangkabau yang berdomisili di daerah ini.

Pengembangan organisasi NU di Tapanuli Selatan dibagi kepada lima wilayah pengembangan, yaitu wilayah Mandailing, wilayah Natal dan Batang Natal, wilayah Padang Lawas termasuk daerah Barumun, wilayah Angkola-Sipirok, dan wilayah Batang Toru arah ke Sibolga. Para pemuka agama seperti ulama dan guru-guru agama pada madrasah di kelima wilayah ini telah berpartisipasi aktif terhadap pendirian dan mensosialisasikan organisasi NU sebagaimana yang dihasilkan oleh Kongres Kaum Muslimin se-Tapanuli tanggal 7-9 Februari 1947 di Padangsidimpuan. Madrasah Musthafawiyah Purbabaru sebagai lembaga pendidikan Islam yang berdiri sejak tahun 1915 telah dijadikan sebagai 
pusat belajar agama Islam di Tapanuli. Muridnya terdiri atas berbagai daerah dan setelah menamatkan pelajarannya dengan membawa ijazah Musthafawiyah ke kampung halamannya adalah mempunyai suatu kebanggaan dan nilai tersendiri bagi setiap lulusan. Predikat lulusan Musthafawiyah masih sangat berharga bagi masyarakat pada waktu itu, dan umumnya mereka berkegiatan dalam bidang pendidikan Islam yang sebelumnya belum tertata dengan baik. Posisi lulusan Musthafawiyah yang terhormat di tengah masyarakat inilah yang cukup berperan terhadap pembinaan dan pengembangan organisasi Nahdlatul Ulama di wilayah Tapanuli Selatan. Madrasah yang dibangun oleh masyarakat setempat sebagian besar memakai nama/lambang NU.

Setelah Indonesia merdeka tahun 1945, dan tahun 1946 dibentuk Jawatan Agama yang kemudian berubah dengan Departemen Agama. Di Sumatera Utara, instansi ini mulai dibentuk tahun 1946 dengan nama Jawatan Agama. Untuk mengisi tenaga di instansi ini, kebanyakan diambil dari yang berpendidikan agama Islam. Sebagaimana disebut di atas, bahwa Madrasah Musthafawiyah adalah pusat pendidikan Islam di daerah Tapanuli Selatan waktu itu. Sebab itu, lulusan Madrasah inilah yang mengisi tenaga/ pegawai di Jawatan Agama yang dimulai dengan sukarela. Dengan masuknya lulusan Madrasah Musthafawiyah menjadi pegawai Jawatan Agama, semakin berpeluang bagi mereka untuk melakukan pembinaan dan pengembangan organisasi NU. Jawatan Agama di Kabupaten Tapanuli Selatan atau Padangsidimpuan dijabat oleh Syekh Ali Hasan ad-Dary. Ia adalah lulusan Musthafawiyah, kemudian belajar beberapa tahun di Makkah dengan spesialisasi ilmu Hadis dan pernah mengajar di Madrasah Musthafawiyah. Pada Kongres NU pertama tahun 1950 di Padangsidimpuan, ia masuk dalam kepengurusan wilayah sebagai Wakil Konsul. Kemudian, pejabat agama di jawatan agama ini digantikan oleh kader-kader NU sampai lahirnya Orde Baru. 
Pengembangan NU di luar Tapanuli Selatan seperti daerah Tapanuli Tengah dan Sibolga juga banyak dilakukan para pemuka agama terutama yang berasal dari lulusan Pesantren Musthafawiyah yang telah banyak tersebar di berbagai daerah sebagai guru agama. Selain lulusan Pesantren Musthafawiyah, pendiri organisasi ini juga dilakukan oleh para anggota Pengurus Wilayah NU yang bermukim di Sibolga dan sekitarnya. Berdirinya madrasah-madrasah Islamiyah di pedesaan tentu sangat membantu dalam pengembangan organisasi NU, di mana pimpinan dan tenaga pengajarnya kebanyakan dari lulusan Madrasah Musthafawiyah. Di samping sebagai pemuka agama, mereka juga menjadi pegawai di jawatan atau Departemen Agama tingkat kecamatan (pejabat agama). Di daerah Tapanuli Tengah, sebelum kemerdekaan Indonesia 1945 telah banyak lulusan Pesantren Musthafawiyah yang mengajar di madrasah-madrasah yang dibangun oleh masyarakat, seperti di daerah Barus dan Sorkam. Mereka ada yang berasal dari daerah ini atau sengaja didatangkan dari daerah Mandailing. Penyediaan tenaga agama Islam di kawasan Tapanuli Tengah dilakukan secara terprogram setiap tahun, yaitu oleh masyarakat setempat langsung meminta kepada Syekh Musthafa Husein sebagai pimpinan Madrasah Musthafawiyah Purbabaru pada saat menamatkan lulusannya.

Selain lulusan Pesantren Musthafawiyah di atas, di Barus terdapat seorang tokoh nasional dari organisasi Nahdlatul Ulama bernama H. Zainul Arifin, tetapi ia bermukim di Jakarta dan termasuk orang Sumatera Utara pertama yang masuk dalam jajaran Pengurus Besar Nahdlatul Ulama bersama-sama dengan Syekh Musthafa Husein di bagian Syuriah pada tahun 1950-an. Pusat pembinaan dan pengembangan NU di Tapanuli Tengah adalah di Barus dan Sorkam, dan sama halnya di Tapanuli Selatan berpusat di Purbabaru Mandailing. H. Zainul Arifin adalah termasuk dalam deretan Pahlawan Nasional, namanya telah diabadikan di berbagai kota besar di Indonesia dengan memakai Jalan Zainul Arifin. 
Di Sumatera Timur, pendirian dan pengembangan NU baru dilakukan setelah tahun 1952 bersamaan dengan pemindahan sekretariat wilayah ke ibukota Propinsi Sumatera Utara. Pendirian dan pengembangan NU di daerah ini berbeda dengan di Tapanuli Selatan yang relatif lebih cepat berkembang. Di Sumatera Timur pada waktu itu telah berdiri Al Jam'iyatul Washliyah tahun $1930^{17}$ yang dimulai dari berdirinya Maktab Islamiyah Tapanuli yang disponsori oleh ulama dan tokoh-tokoh agama yang berasal dari Mandailing, Tapanuli Selatan. Dari sudut paham keagamaan bahwa Al Jam'iyatul Washliyah yang bermazhab Syâfíi tidak berbeda dengan mazhab yang dipakai oleh NU. Pendekatan yang dilakukan NU pada masyarakat Melayu di Sumatera Timur adalah melalui pendekatan kultural, yaitu melalui pemuka-pemuka elit tradisional yang mempunyai kharismatik. Di antara pemuka masyarakat tersebut adalah Syekh Abdullah Afifuddin Tanjung Pura Langkat, Tengku Yafidzham (termasuk keluarga/keturunan Sultan Serdang di Perbaungan), Hasan Darus (termasuk pengusaha kaya di Langkat), dan Tengku Amiruddin di daerah Percut/ Batang Kuis. Sedangkan di Kesultanan Deli sudah lebih dulu dipengaruhi oleh organisasi Al Washliyah. Dilihat dari sudut paham keagamaan, Kesultanan Deli, Sumatera Timur, menganut paham Kaum Tua (Ahlussunnahwaljamaah), sedangkan paham Kaum Muda yang dikembangkan oleh Muhammadiyah tidak berpengaruh di Kesultanan.

Konferensi NU wilayah Sumatera Utara ketiga tahun 1953 merupakan era penggabungan Konsulat NU Wilayah Sumatera Utara di Padangsidimpuan dan Perwakilan Konsulat Wilayah di Medan. Sebab itu, dalam kepengurusan Wilayah telah masuk orang-orang Melayu, jadi tidak lagi dimonopoli etnis Mandailing/ Tapanuli Selatan. Di antara ulama kharismatik di daerah Langkat adalah Syekh Abdullah Afifuddin, ia masuk di Wakil Syuriah bersama Syekh Musthafa Husein. Setelah Syekh Musthafa Husein 
wafat tahun 1955, Syekh Abdullah Afifuddin menduduki jabatan Syuriah NU wilayah Sumatera Utara sampai periode 1969-1971 (Konferensi NU wilayah Sumatera Utara ketujuh di Prapat tahun 1969). Selain Syekh Abdullah Afifuddin, masuk juga Tengku Yafizham di jajaran Tanfidziyah. Ia adalah seorang intelektual/ terpelajar dari keluarga raja-raja di Kesultanan Serdang. Masuknya ulama dan pemuka masyarakat etnis Melayu tentu akan mempermudah gerakan percepatan dan berkembangnya organisasi Nahdlatul Ulama di kalangan masyarakat Melayu Sumatera Timur. Selanjutnya, keluarga Darus dari Langkat bergabung ke dalam NU. Keluarga ini termasuk yang berpengaruh di masyarakat Langkat, umumnya dari keluarga terpelajar dan berpendidikan. Selain mereka, juga terdapat nama H. Hasan Darus yang masuk dalam kepengurusan NU wilayah Sumatera Utara. ${ }^{18}$

Wilayah-wilayah pengembangan Nahdlatul Ulama di Sumatera Timur adalah Langkat, Deli Serdang dan sebagian Kota Medan. Integrasi kultural antara etnis Mandailing Tapanuli Selatan dengan etnis Melayu Sumatera Timur terjalin dengan baik, karena telah terlebih dahulu menghayati dan memahami ajaran Islam menurut paham Ahlussunnahwaljamaah. Demikian juga sistem budaya masyarakat Mandailing di Sumatera Timur berinteraksi secara ilmiah. Sebagai contoh, seorang Mandailing yang migrasi di Sumatera Timur banyak yang tidak memakai marganya dan menyesuaikan dengan sebutan nama-nama Islam (istilah bahasa Arab). Demikian juga banyak terjadi asimilasi melalui jalur perkawinan antar etnis. Berbeda halnya dengan etnis Batak (Toba) yang masih menganut agama Kristen, di mana terlihat mengalami kesulitan berintegrasi dan berasimilasi dengan etnis Melayu karena dihambat oleh ajaran agama yang berlainan. ${ }^{19}$

Pengembangan NU melalui jalur struktural tidak kalah pentingnya dari pendekatan kultural di atas. Masuknya tokohtokoh NU ke birokrasi pemerintahan (Departemen Dalam Negeri 
dan Departemen Agama) sangat besar pengaruhnya dalam pengembangan NU di Sumatera Utara, sebagaimana terlihat setelah organisasi ini menjadi partai politik tahun 1952. Munculnya Partai NU sebagai empat besar pemenang dalam Pemilu 1955 menjadi motivasi bagi mereka untuk lebih banyak membina dan mengembangkan NU selanjutnya. Pada Pemilu 1955, dengan munculnya Syekh Musthafa Husein Purbabaru sebagai calon urutan pertama dari NU Sumatera Utara untuk menjadi anggota DPR-RI menambah motivasi bagi kalangan Nahdiyyin untuk membina dan mengembangkan NU di seluruh pedesaan di Sumatera Utara, terutama bagi mereka yang lulusan Madrasah Musthafawiyah yang telah tersebar di berbagai daerah pada waktu itu.

Kemenangan Nahdlatul Ulama dalam Pemilihan Umum 1955 di tingkat nasional setelah PNI dan Masyumi, pada satu sisi memberikan pengaruh yang besar terhadap pengembangan NU di Sumatera Utara. Tetapi, personalia kepengurusan NU wilayah Sumatera Utara hasil konferensi keempat di Medan tahun 1958 terdiri atas generasi atau wajah-wajah baru antara lain H. Abir Zuhdy Daulay, H. Muda Siregar, Luat Harahap, Djamaluddin Tambunan di Pengurus Harian (Tanfidziyah). Demikian pula di lembaga badan otonom seperti Bangun Nasution di Sarumusi, H. Ismail Sulaiman di Gerakan Pemuda Anshor. Pada Konferensi NU wilayah Sumatera Utara kelima di Berastagi tahun 1963, selain personalia periode sebelumnya, masuk generasi muda seperti OK H. Imran, Karimuddin, dan OK. Hasan Darus dari etnis Melayu. Dari etnis Mandailing masuk antara lain Burhanuddin Nasution dan Basyar Harahap. Pada Konferensi NU keenam di Medan tahun 1967 terjadi perubahan kepengurusan Tanfidziyah yaitu Ketua tetap H.M.Nuddin Lubis, Wakil Ketua terdiri dari OK. Haji Hasan Darus, Angin Bugis Lubis (Baru), Haji Ismail Sulaiman (sebelumnya Ketua GP Anshor), dan Bangun Nasution (sebelumnya Ketua Sarbumusi). Jabatan Sekretaris diduduki 
oleh Haji Abdul Djabbar Nasution, Basyar Harahap, dan Kamaluddin Lubis.

Pada Konferensi NU ketujuh di Prapat tahun 1969, terjadi lagi pergeseran posisi dalam jabatan Syuriah dan Tanfidziyah. Di Syuriah sebagai Rais tetap dijabat oleh Syekh Abdullah Afifuddin (Melayu) dan Wakil Rais dijabat Haji Makrum Thahir (Mandailing) dan Syekh H. Adrian Yahya Lubis (Mandailing), dan Katib Syuriah dijabat oleh H. Ali Husin Siregar (Mandailing) dan H. Mara Ludin Rangkuti (Mandailing) ditambah dengan anggota terdri dari Syekh Dja'far Abdul Wahab (Mandailing), H. Djamin Dahlan (Melayu) dan Fahruddin Razy Harahap (Mandailing). Sedangkan pengurus di Tanfidziyah terdiri atas: Ketua, H. Sulaiman (Mandailing), H. Amiruddin (Melayu), Hasan Basri Batubara (Mandailing), H. Yusuf Tengku Imam Hasibuan (Mandailing) dan Tengku Yafizham, SH. (Melayu). Sedangkan jabatan Sekretaris dijabat oleh: Angin Bugis Lubis (Mandailing), Basyar Harahap (Mandailing), Baharuddin Lubis (Mandailing), dan TF. Bako (Dairi). Konferensi NU wilayah Sumatera Utara tahun 1969 ini adalah masa bakti sampai tahun 1971, namun setelah selesai Pemilu 1971, dan pada tahun 1973 terjadi fusi partai politik, di mana Partai NU bersama tiga partai Islam lainnya berfusi dalam Partai Persatuan Pembangunan (PPP). Terjadinya fusi partai politik ini sangat berpengaruh terhadap kehidupan organisasi NU secara nasional. Khusus di Sumatera Utara, telah mulai terjadi kevakuman kepengurusan organisasi termasuk orientasinya semakin tidak jelas. Sistem pembangunan politik yang digariskan pemerintahan Orde Baru secara perlahan terpasungnya kehidupan organisasi sosial keagamaan.

Konsekuensi dari situasi pembangunan politik yang diterapkan oleh permerintah, tokoh-tokoh NU yang masih potensial untuk memegang dan melanjutkan kepengurusan organisasi di seluruh daerah Sumatera Utara semakin menjauh dan menghindar dari 
organisasi NU, terutama bagi mereka yang berstatus Pegawai Negeri Sipil (PNS) atau pengusaha swasta yang masih punya ketergantungan kepada pemerintah. Kenyataan ini termasuk salah satu faktor penghambat hidupnya kembali organisasi NU di Sumatera Utara. Sedangkan faktor lain adalah terjadinya kekosongan jabatan di kepengurusan NU wilayah Sumatera Utara karena konferensi berikutnya tidak pernah terlaksana. Di antara anggota Pengurus Wilayah seperti H.M. Nuddin Lubis berdomisili di Jakarta, dan yang lainnya terlibat di PPP dan memilih jabatan sebagai PNS. Berlarut-larutnya pelaksanaan Konferensi NU wilayah Sumatera Utara memberikan peluang bagi sebagian untuk tidak lagi mempercayai H.M. Nuddin Lubis sebagai Ketua NU wilayah Sumatera Utara. Akhirnya, muncul persimpangan jalan dan konflik internal organisasi, yang pada umumnya disponsori oleh generasi muda NU. Mulai dari saat inilah sampai NU kembali ke Khittah 1926 pada Muktamar NU tahun 1984, kepengurusan NU Wilayah Sumatera Utara penuh dengan muatan-muatan konflik internal. Berkaitan dengan situasi yang kurang menguntungkan di atas, Departemen Agama menjadi pusat pembinaan dan pengembangan organisasi NU, mulai dari pusat sampai daerah-daerah, di seluruh Indonesia, dan secara politis bahwa yang menduduki Menteri Agama harus dari kalangan NU. NU-isasi semakin menguat di Departemen Agama.

Di wilayah Sumatera Utara, hal ini sangat jelas terlihat bahwa yang menduduki jabatan di instansi tersebut sampai ke tingkat kecamatan (Kepala Kantor Urusan Agama) diprioritaskan dari kalangan Nahdlatul Ulama. Sebagai konsekuensi dari pembinaan dan pembangunan kepartaian oleh pemerintah, semua anggota NU yang berstatus PNS memilih untuk tidak melibatkan diri dalam organisasi NU, sehingga terjadi kelangkaan kader atau personalia yang dapat mengelola dan mengurus organisasi. Khusus Departemen Agama yang sebelumnya adalah sarana pengkaderan 
di kalangan tokoh-tokoh NU, pada tahun 1971 jabatan Menteri Agama diberikan kepada Mukti Ali, seorang akademisi dari IAIN Sunan Kalijaga, Yogyakarta. Dengan konsep yang matang, semua tokoh potensial NU tidak lagi diberikan kesepakatan untuk menduduki jabatan strategis mulai dari pusat sampai ke daerah-daerah. Perubahan sistem pembangunan ini sangat terasa bagi masyarakat NU di seluruh Indonesia.

\section{Periode Tahun 1971-1984}

Pada periode ini, pemerintah menyusun kekuatan politik melalui "Sekber Golkar" yang lebih merupakan "partai” pemerintah yang melakukan segala cara untuk menghancurkan partai-partai politik lainnya. Pada pemilu 1971, terdapat empat partai politik Islam sebagai peserta, yaitu PSII, Perti, Parmusi, dan NU. Pada Pemilu tersebut, Partai Nahdlatul Ulama berhasil sebagai pemenang kedua di tingkat nasional. Namun di daerah Sumatera Utara, partai ini hanya mendapat tiga kursi di DPRD Provinsi dan untuk DPR Pusat hanya mendapatkan satu kursi.

Kemenangan mutlak yang diraih oleh Golongan Karya (Golkar) yang diback-up oleh Pemerintah pada Pemilu 1971 memberikan pengaruh yang sangat besar terhadap keberlangsungan organisasi Nahdlatul Ulama khususnya, dan seluruh partai politik pada umumnya. Berbagai peraturan telah diformat sedemikian rupa, sehingga gerak dan pengembangan seluruh organisasi masyarakat benar-benar tidak lagi berkembang atau bisa dikatakan telah terjadi pemasungan secara sistematik. Kepengurusan organisasi NU di tingkat wilayah sampai ke tingkat kecamatan dan malah di beberapa daerah pedesaan dipaksa untuk tidak aktif atau harus meninggalkan kegiatannya dalam organisasi, bagi mereka yang tidak mematuhinya diberikan tindakan dengan berbagai sanksi. Akhirnya, NU di Sumatera Utara mengalami kemunduran yang 
sangat drastis, kader-kader dan pengurus organisasi yang berstatus pegawai negeri harus meninggalkan jabatannya dalam organisasi.

Dari tahun 1973 sampai menjelang pelaksanaan Muktamar NU 1984 merupakan era yang tidak menguntungkan bagi kehidupan NU. Kebiasaan sewaktu NU menjadi partai politik (1952-1973) masih terbawa-bawa di dalam kehidupannya, padahal sejak terjadi fusi partai-partai politik bahwa NU kembali kepada semula sebagai organisasi sosial-keagamaan. Orientasi tokoh-tokoh NU lebih tercurah kepada PPP, karena di berbagai daerah yang menjadi pengurus partai ini adalah dari unsur Nahdlatul Ulama, termasuk di Sumatera Utara. H.M. Nuddin Lubis sebagai Ketua NU wilayah Sumatera Utara lebih lama berada di Jakarta, karena ia termasuk dalam jajaran Pengurus Pusat PPP, dan di kepengurusan PBNU ia dipercaya sebagai salah seorang Ketua. Akibat dari ketidakaktifan H.M. Nuddin Lubis dan pengurus lainnya mengurusi NU wilayah membuka peluang bagi kader-kader lain untuk mengambil alih kepemimpinan NU wilayah Sumatera Utara. Hal ini sebenarnya telah mulai muncul pada saat konferensi NU di Prapat tahun 1969, di mana sebagian generasi mudanya mulai menggugat kepemimpinan NU wilayah termasuk terlalu lama dijabat oleh H.M. Nuddin Lubis (sejak berdiri 1947 telah menjadi unsur ketua). ${ }^{20}$

Gerakan-gerakan yang disponsori oleh generasi muda NU di pusat, yang dimotori oleh Abdurrahman Wahid sejak tahun $1982^{21}$ berusaha supaya Nahdlatul Ulama kembali ke Khittah 1926, yaitu kembali menjadi Jam 'iyah sebagaimana semula pada saat NU berdiri tahun $1926 .{ }^{22}$ Semangat dan emosi untuk menjadikan NU sebagai kekuatan dan basis perjuangan umat Islam yang berpaham Ahlussunnahwaljamaah semakin kokoh dan kuat kembali di kalangan jamaahnya, termasuk di kalangan para kiai dan ulama. Kebangkitan kembali membangun organisasi secara emosional ditopang pula oleh perlakuan dan sikap kelompok Parmusi atau Muslimin Indonesia di tubuh PPP yang dikomandani 
J. Naro, SH. sebagai Ketua Umum PPP. Pada Pemilu tahun 1982, tokoh-tokoh NU yang selama ini mendominasi legislatif di tingkat pusat dan beberapa daerah tersisih sama sekali pada saat penetapan calon anggota legislatif. Pada Muktamar NU tahun 1984, gerakan-gerakan yang dimotori oleh generasi muda NU berhasil mengambil keputusan politik bersejarah, yaitu menggusur KH. Dr. Idham Khalid dan Ketua Umum Tanfidziyah dan digantikan oleh $\mathrm{H}$. Abdurrahman Wahid, dan menarik dukungan NU secara organisatoris dari PPP, sehingga Nahdlatul Ulama kembali ke Khittah 1926. Beberapa orang lompat pagar, di mana sebelumnya bukan masuk anggota Jam'iyah NU, tetapi karena kelangkaan kader lahirnya menjadi pengurus NU wilayah Sumatera Utara. Sedangkan yang lainnya, memang sejak awal bahwa mereka adalah kader-kader NU, namun dari segi perilaku ke NU-an sebagai organisasi Islam kurang terlihat pada diri mereka. Hal inilah yang terjadi pada jajaran kepemimpinan NU di Sumatera Utara periode belakangan ini. ${ }^{23}$

Masa kevakuman kepemimpinan NU wilayah Sumatera Utara memberikan dampak yang besar pula terhadap organisasi otonom, seperti Muslimat, Fatayat, dan GP Ansor. Kepemimpinan pada organisasi/badan otonom ini mengalami krisis pengkaderan, salah satu yang diharapkan adalah munculnya tokoh-tokoh dari alumni PMII sebagai organisasi mahasiswa yang cirinya sama dengan Nahdlatul Ulama ternyata mengalami kebuntuan, karena mereka ini telah berpendidikan sehingga pola berpikirnya lebih rasional. Hal ini juga terjadi semacam keragu-raguan karena sebagian yang bukan berasal dari akademisi tersebut lebih mengacu kepada orientasi kepentingan dan kekuasaan. Krisis ketidakpercayaan internal ini berimbas pula terhadap lepasnya beberapa lembaga perguruan NU menjadi milik perorangan, dan sebagian berubah menjadi nama lain. ${ }^{24}$ 
Kepengurus NU wilayah Sumatera Utara sejak tahun 1971 telah mengalami pergeseran dari tradisi yang dibangun sebelumnya, yaitu setelah H.M. Nuddin Lubis berdomisili di Jakarta dan ia meninggalkan suatu kesan yang kurang baik, terutama di kalangan generasi muda NU. Pada saat berlangsung Pemilu 1971, kepengurusan NU di Sumatera Utara dan daerah kabupaten/kota masih terlihat adanya kebersamaan dan orientasi kegiatan yang dilakukan, tetapi setelah terjadi fusi partai-partai tahun 1973, mulai dirasakan kelangkaan kader ntuk menjadi pengurus organisasi. Tokoh dan pimpinan NU yang sebelumnya mulai mengambil jarak dengan NU karena mereka lebih mengutamakan penyelamatan kedudukan sebagai pejabat atau PNS. Sedangkan tokoh-tokoh lainnya lebih sibuk dalam kepengurusan PPP yang merupakan partai politik hasil dari fusi beberapa partai Islam (NU, Parmusi, Perti dan PSSI). Kepengurusan NU wilayah Sumatera Utara menjadi status quo, dan akhirnya kelompok yang berseberangan dengan kelompok H.M. Nuddin Lubis melakukan Konferensi NU wilayah di tahun 1980 tanpa dihadiri Pengurus Wilayah NU sebelumnya.

Mulai saat inilah terlihat muncul konflik di kalangan elit dan kokoh NU di Sumatera Utara. Pada waktu Muktamar NU tahun 1979 di Semarang, H.M. Nuddin Lubis telah menjadi salah satu unsur Ketua di PBNU. Ia sempat dipermalukan oleh sebagian utusan NU Sumatera Utara dalam muktamar, tepatnya di saat ia memimpin sidang pleno, terutama oleh $\mathrm{H}$. Hasan Basri Batubara ${ }^{25}$ yang menggugat kedudukan H.M. Nuddin Lubis sebagai Ketua NU wilayah Sumatera Utara. Konflik di kalangan tokoh NU di Sumatera Utara terus berlangsung sampai tahun 1990-an. Hasan Basri Batubara adalah satu-satunya unsur Ketua NU wilayah Sumatera Utara periode 1969-1971 (hasil Konferensi NU ke-7 di Prapat 1969), karena yang lainnya tidak lagi aktif, dan sebagian telah meninggal dunia. Setelah fusi partai-partai di tahun 1973, Hasan Basri Batubara menjadi anggota DPRD Propinsi Sumatera 
Utara (menggantikan H.M. Yusuf T. Imam Hasibuan karena wafat tahun 1971), dan ia memainkan peranan cukup sentral dalam perjalanan sejarah organisasi NU.

Konflik elit NU di wilayah Sumatera Utara terus berlanjut. Pada tahun 1980-an, H. Hasan Basri Batubara perah dipecat dari kepengurusan NU wilayah Sumatera Utara, tetapi ia tetap menjadi anggota DPRD Propinsi Sumatera Utara dari Fraksi PPP dan menjabat sebagai Wakil Ketua DPRD Propinsi Sumatera Utara. Sebagai politikus, ia cukup dekat dengan Pemerintah Orde Baru, dan walaupun telah dinonaktifkan dari NU, ia tetap mempunyai posisi yang penting di PPP Sumatera Utara. Dalam situasi demikian ini, kepemimpinan NU Wilayah Sumatera Utara beralih kepada Marah Halim Siregar sebagai mantan Ketua GP Ansor Sumatera Utara. Sejak tahun 1968, ia telah berseberangan dengan H.M. Nuddin Lubis. Berangkat dari pengalaman dan perilaku yang dimilikinya, selama kepengurusan NU berada di tangannya, mulai masuk orang-orang yang belum dikenal dalam jajaran NU sebelumnya sebagai Pengurus Wilayah NU Sumatera Utara. Akhirnya, pengurus NU di Sumatera Utara mulai mendapat ketidakpercayaan dari kalangan anggota NU yang berujung kepada terjadinya dualisme dalam kepengurusan NU. Hal ini sekurang-kurangnya berjalan sampai periode Konferensi NU tahun 1990.

Perpecahan dalam internal NU wilayah Sumatera Utara tidak hanya berlangsung sampai di sini, tetapi berimbas pada organisasi otonom NU seperti organisasi Muslimat, Fatayat, dan GP Ansor, serta beberapa Pengur Cabang NU di kabupaten/ kota. Marah Halim Siregar sebagai Ketua NU wilayah Sumatera Utara telah menciptakan banyak peluang konflik. Di antaranya adalah dengan penjualan sebagian aset-aset organisasi seperti tanah di Jalan Malaka Medan. Kalangan yang merasa sebagai warga Jam'iyah NU akhirnya semakin menjauh dari organisasi. 
Hal ini terlihat terutama di kalangan alumni Pesantren Musthafawiyah Purbabaru Mandailing. Para alumni Pesantren Musthafawiyah sebagian besar mengambil jarak dengan organisasi NU dengan mendirikan organisasi Keluarga Abituren Musthafawiyah tahun 1982 yang berpusat di Medan ${ }^{26}$ dan sebagiannya masuk dan aktif dalam organisasi Al Washliyah. Pendirian organisasi alumni Musthafawiyah ini disponsori beberapa alumni senior dan generasi mudanya di Medan. Organisasi ini untuk pertama kali musyawarah dilaksanakan di Pesantren al-Kautsar di Jalan Pelajar, Medan. Pada tahun 1984, dilaksanakan musyawarah pertama (semacam kongres) sekaligus reuni akbar alumni Musthafawiyah yang dihadiri oleh pengasuh dan pimpinan Pesantren Musthafawiyah Syekh H. Abdullah Musthafa beserta ulama dan para guru Musthafawiyah.

Pada tahun 1990, dilaksanakan konferensi NU wilayah Sumatera Utara bertempat di Sibuhuan, Tapanuli Selatan. Kepengurusan NU wilayah beralih kepada H. Baharuddin Lubis, SH. (mantan Walikota Sibolga, dan pernah masuk di jajaran Pengurus Wilayah NU di masa kepemimpinan H.M. Nuddin Lubis). Ia secara moril mendapat dukungan dari Pemerintah di Propinsi Sumatera Utara, di mana pada waktu Gubernur Sumatera Utara dijabat oleh Raja Inal Siregar, dan pada saat itu H. Baharuddin Lubis, SH. menjabat sebagai Kepala Dinas Pendidikan Sumatera Utara. Di antara Pengurus Syuriah NU Sumatera Utara adalah Syekh Muchtar Muda Nasution (Sibuhuan, Tapanuli Selatan), KH. Ahmad Nasution (Medan) dan ditambah dengan generasi yang lebih muda. Kepengurusan di jajaran Tanfidziyah mulai memasukkan generasi muda yang berstatus PNS atau yang aktif di berbagai perusahaan swasta.

Susunan kepengurusan periode ini berbeda dengan kepengurusan NU sebelumnya, seperti terlihat masuknya tokoh-tokoh muda yang terpelajar dengan harapan dapat melakukan perubahan, dimana selama ini citra organisasi NU di Sumatera Utara mengalami 
keterpurukan jika dibanding dengan organisasi keislaman lainnya. Sebagaimana tradisi yang dibangun oleh organisasi NU sejak berdiri adalah bahwa pengurus harus mempunyai identitas keislaman yang berpaham Ahlussunnahwaljamaah yang harus tercermin dalam semua usaha, kegiatan, perilaku dan tindakan pemimpinnya, tetapi belakangan agaknya belum seluruhnya tercermin pada pengurus yang baru ini. Memang, menyangkut lingkup keagamaan (Islam) merupakan otoritas para ulama yang duduk dalam Syuriah, tetapi pengurus pada tingkat Tanfidziyah kurang mendukung identitas tersebut. Kepengurusan periode 1990-1994 ini masih terlihat adanya kerenggangan dengan munculnya kembali kelompokkelompok yang berseberangan, karena mereka merasa lebih pantas menjadi pemimpin organisasi. Karena menurut pendapat mereka adalah tidak logis masuknya orang yang bukan kader NU di jajaran kepengurusan organisasi.

Pada tahun 1994, dilaksanakan Konferensi NU ke-12 di Medan. Konferensi ini berhasil menyusun pengurus NU wilayah Sumatera Utara periode 1994-1998. Komposisi kepengurusan di Syuriah tetap menempatkan Syekh H. Muchtar Muda Nasution sebagai Rais Syuriah dilengkapi dengan wajah-wajah baru yang lebih junior seperti Asnan Ritonga, Burhanuddin Nasution, dan Syekh Ali Akbar Marbun. Sedangkan di Tanfidziyah dijabat oleh Abbas Pulungan, seorang aktivis PMII di IAIN Sunan Kalijaga Yogyakarta tahun 1972-1977, dan ia juga sewaktu mahasiswa adalah Ketua Umum Dewan Mahasiswa di perguruan tinggi yang bersangkutan. Ketika Abbas Pulungan menjadi Ketua NU wilayah Sumatera Utara, ia kembali memasukkan alumni Pesantren Musthafawiyah Purbabaru Mandailing di jajaran kepengurusan NU, baik di Syuriah maupun di Tanfidziyah.

Menurut catatan sejarah perkembangan NU di Sumatera Utara, baru kedua kali ini lulusan Musthafawiyah menjadi Ketua NU wilayah Sumatera, setelah H.M. Nuddin Lubis yang menjabat 
selama enam periode (1947-1971). NU wilayah Sumatera Utara periode ini belum banyak berbuat, karena pada bulan Desember 1994 berlangsung Muktamar NU ke-29 di Pesantren Cipasung Tasikmalaya, Jawa Barat yang banyak menyita pemikiran. Sebelum muktamar dilaksanakan, ada isu bahwa pemerintahan Orde Baru berusaha untuk menggeser KH. Abdurrahman Wahid dan agar tidak lagi dipilih dalam muktamar NU sebagai Ketua Umum PBNU. Gagasan untuk menggeser KH. Abdurrahman Wahid ternyata tidak berhasil.

Kepengurusan NU wilayah Sumatera Utara periode ini hanya berlangsung sekitar dua tahun. Pada tahun 1996, Abbas Pulungan mengundurkan diri sebagai Ketua Tanfidziyah NU wilayah Sumatera Utara. Kepengurusan NU wilayah Sumatera Utara dilanjutkan oleh Ketua I, yaitu Prof. Drs. H.A. Rivai Siregar sampai akhir periode 1998. Pada tahun 1998, dilaksanakan Konferensi NU wilayah Sumatera Utara di Medan, dimana Prof. Drs. A. Rivai Siregar terpilih menjadi Ketua Tanfidziyah. Setelah muktamar NU ke-30 tahun 1999 yang berlangsung di Pesantren Lirboyo, Kediri Jawa Timur, Prof. Drs. A. Rivai Siregar masuk dalam unsur Ketua PBNU, dan sebab itu ia harus nonaktif di kepengurusan NU wilayah Sumatera Utara. Kepengurusan NU wilayah Sumatera Utara dijabat oleh Drs. H. Anwar Nur Siregar, kemudian pada Konferensi NU berikutnya, tahun 2003, ia terpilih menjadi Ketua Tanfidziyah NU wilayah Sumatera Utara. Kemudian, NU dipimpin oleh Ashari Tambunan (pada saat ini Bupati Kabupaten Deli Serdang, Sumatera Utara) dan NU sampai saat ini dipimpin oleh Afifuddin Lubis (pernah menjadi Pejabat Walikota Medan tahun 2005) untuk periode 2015-2017. 


\section{Penutup}

Berdasarkan kajian di atas, dapat disimpulkan tiga hal berikut. Pertama, pendirian Nahdlatul Ulama di Sumatera Utara diinisiasi oleh alumni Pesantren Musthafawiyah, sebuah pesantren tradisional yang didirikan oleh Syekh Musthafa Husein. Mayoritas alumni pesantren ini berasal dari suku Mandailing. Tetapi belakangan, kalangan santri tidak lagi memegang tampuk kepemimpinan tanfidziyah NU di Sumatera Utara. Atas usaha H.H. Nuddin Lubis dan persetujuan Syekh Musthafa Husein, diadakan tabligh akbar, dan dalam kegiatan tersebut disepakati untuk mengadakan Kongres Kaum Muslimin se-Tapanuli pada tanggal 7-9 Februari 1947 yang dihadiri para pemuka umat Islam.

Kedua, awal kehadiran Nahdlatul Ulama di Sumatera Utara bermula dari kawasan Tapanuli lalu kemudian berpusat di Kota Medan dimana dua organisasi Islam lain telah lebih dahulu muncul, yaitu Al Washliyah dan Muhammadiyah. Pada tahun 1953, konferensi NU wilayah Sumatera Utara menggabungkan konsulat NU Padangsidimpuan dan Perwakilan Konsulat Wilayah di Medan. Sejak itulah, NU di Sumatera Utara tidak lagi didomisili oleh kelompok etnis Mandailing, tetapi sudah masuk tokohtokoh Melayu seperti Syekh Abdullah Afifuddin dan Tengku Haji Jafizham. Akhirnya, NU tidak saja berkembang di kawasan Tapanuli, tetapi juga di Sumatera Timur.

Ketiga, pengembangan NU semakin diperkuat oleh keberadaan kader NU di birokrasi pemerintahan. Beberapa tokoh NU masuk di Departemen Dalam Negeri dan Departemen Agama. Bahkan bisa dikatakan telah terjadi NU-isasi di birokrasi pemerintahan di Sumatera Utara. 


\section{Pustaka Acuan}

Barton, Greg, dan Andrée Feillard. "Nahdlatul Ulama, Abdurrahman Wahid and Reformation: What Does NU's November 1997 National Gathering Tell Us?,” dalam Studia Islamika, Vol. 6, No. 1, 1999.

Bush, Robin. "Redefining "Political Islam" in Indonesia: Nahdlatul Ulama and Khittah '26," dalam Studia Islamika, Vol. 7, No. 2, 2000.

Bush, Robin. Nahdlatul Ulama and the Struggle for Power within Islam and Politics in Indonesia. Singapore: ISEAS, 2009.

Fata, Ahmad Khoirul, dan M. Ainun Najib. "Kontekstualisasi Pemikiran KH. Hasyim Asy'ari tentang Persatuan Umat Islam,” dalam MIQOT: Jurnal Ilmu-ilmu Keislaman, Vol. 38, No. 2, 2014.

Fealy, Greg dan Bernhard Platzdasch, "The Masyumi Legacy: Between Islamist Idealism and Political Exigency," dalam Studia Islamika, Vol. 12, No. 1, 2005.

Hasan, Mohammad Tolchah. "Mafhum Ahl al-Sunnah wa alJama'ah 'Inda Jam'îyah Nahdah al-'Ulama'," dalam Studia Islamika, Vol. 12, No. 1, 2005.

Hilmy, Masdar. "Quo-Vadis Islam Moderat Indonesia? Menimbang Kembali Modernisme Nahdlatul Ulama dan Muhammadiyah," dalam MIQOT:Jumal Ilmu-ilmu Keislaman, Vol. 36, No. 2, 2012.

Ismail, Faisal. "The Nahdlatul Ulama: Its Early History and Contribution to the Establishment of Indonesian State," dalam Journal of Indonesian Islam, Vol. 5, No. 2, 2011.

Ja'far. "Peran Al Jam 'iyatul Washliyah dalam Merevitalisasi Madhhab Shafi'i di Era Kontemporer," dalam Justicia Islamica: Jurnal Kajian Hukum dan Sosial, Vol. 13, No. 1, 2016.

Ja'far. "Respons Dewan Fatwa Al Jam'iyatul Washliyah terhadap Isu Akidah dan Syariah di Era Global," dalam al-Manahij: Jurnal Kajian Hukum Islam, Vol. 10, No. 1, 2016. 
Langenberg, Michael van. "Sumatera Timur: Mewadahi Bangsa Indonesia dalam Sebuah Keresidenan di Sumatera," dalam Audrey R. Kahin (ed.). Pergolakan Daerah pada Awal Kemerdekaan. Jakarta: Grafiti Pers, 1990.

Mansur, Ahmad. "Suffering from 'Political Exhaustion': The Dynamics of Nahdlatul Ulama (NU) in Indonesia's Political Arena," dalam Journal of Indonesian Islam, Vol. 3, No. 1, 2009.

Masyhuri, Aiz (ed.). Masalah Keagamaan Nahdlatul Ulama: Hasil Muktamar dan Munas Ulama Kesatu 1926 sampai Keduapuluh Sembilan 1994. Surabaya: RMI dan Dinamika Press, 1997.

Munhanif, Ali. "The Khittah of 1926 Reexamined: Views of the NU in Post-Cipasung Congress," dalam Studia Islamika, Vol. 3, No. 1996.

Niam, Khoirun. "Nahdlatul Ulama and the Production of Muslim Intellectuals in the Beginning of 21st Century Indonesia," dalam Journal of Indonesian Islam, Vol. 11, No. 2, 2017.

Salamuddin. "Teologi Rasional Pada Pesantren Tradisional: Telaah Konsep Teologi pada Buku Daras Teologi di Pesantren Musthafawiyah," dalam MIQOT:Jurnal Ilmu-ilmu Keislaman, Vol. 38, No. 1, 2014.

Saragih, Aliman. "Kontribusi Al Jam'iyatul Washliyah terhadap Kemerdekaan Indonesia (1930-1950)," dalam MIQOT:Jurnal Ilmu-ilmu Keislaman, Vol. 40, No. 1, 2016.

Siddik, Dja'far dan Ja'far. Al-Ittihadiyah: Delapan Dasawarsa Menerangi Nusantara. Medan: Perdana Publishing, 2017.

Siddik, Dja'far. "Dinamika Organisasi Muhammadiyah di Sumatera Utara," dalam Journal of Contemporary Islam and Muslim Societies, Vol. 1, No. 1, 2017.

“Apa, Sesudah NU Balik Kanan ke Khittah 1926," Suara Pembaruan, 5 Maret 1988. 
VOL. 2 NO. 1 JANUARI-JUNI 2018

\section{Catatan Akhir:}

${ }^{1}$ Perkembangan awal NU dan kontribusinya bagi NKRI bisa dilihat dalam Faisal Ismail, "The Nahdlatul Ulama: Its Early History and Contribution to the Establishment of Indonesian State," dalam Journal of Indonesian Islam, Vol. 5, No. 2, 2011, pp. 247-282.

${ }^{2}$ Muktamar NU ke-20 tahun 1954 di Surabaya mengeluarkan keputusan keagamaan tentang kepemimpinan politik nasional yang menyatakan bahwa Presiden Soekarno selaku pemimpin politik nasional dan perangkat-perangkat kenegaraan lainnya merupakan waliy al-amr darurin bi al-syawkah, Aiz Masyhuri (ed.), Masalah Keagamaan Nahdlatul Ulama: Hasil Muktamar dan Munas Ulama Kesatu 1926 sampai Keduapuluh Sembilan 1994 (Surabaya: RMI dan Dinamika Press, 1997), h. 207-208.

${ }^{3}$ Greg Fealy dan Bernhard Platzdasch, "The Masyumi Legacy: Between Islamist Idealism and Political Exigency," dalam Studia Islamika, Vol. 12, No. 1, 2005, pp. 73-100.

${ }^{4}$ Ahmad Mansur, "Suffering from 'Political Exhaustion': The Dynamics of Nahdlatul Ulama (NU) in Indonesia's Political Arena," dalam Journal of Indonesian Islam, Vol. 3, No. 1, 2009, pp. 239-244.

${ }^{5}$ Robin Bush, Nahdlatul Ulama and the Struggle for Power within Islam and Politics in Indonesia (Singapore: ISEAS, 2009), h. 24-64.

${ }^{6}$ Mohammad Tolchah Hasan, "Mafhûm Ahl al-Sunnah wa al-Jamâ'ah 'Inda Jam'îyah Nahah al-'Ulamâ,," dalam Studia Islamika, Vol. 12, No. 1, 2005, pp. 131-154.

${ }^{7}$ Dja'far Siddik, "Dinamika Organisasi Muhammadiyah di Sumatera Utara," dalam Journal of Contemporary Islam and Muslim Societies, Vol. 1, No. 1, 2017, h. 1-40.

${ }^{8}$ Ja'far, "Peran Al Jam 'iyatul Washliyah dalam Merevitalisasi Madhhab Shafi'i di Era Kontemporer," dalam Justicia Islamica: Jurnal Kajian Hukum dan Sosial, Vol. 13, No. 1, 2016, h. 1-29; Ja'far, "Respons Dewan Fatwa Al Jam'iyatul Washliyah terhadap Isu Akidah dan Syariah di Era Global," dalam al-Manahij: Jurnal Kajian Hukum Islam, Vol. 10, No. 1, 2016.

${ }^{9}$ Ahmad Khoirul Fata, M, Ainun Najib, "Kontekstualisasi Pemikiran KH. Hasyim Asy'ari tentang Persatuan Umat Islam,” dalam MIQOT: Jurnal Ilmu-ilmu Keislaman, Vol. 38, No. 2, 2014, pp. 319-334.

${ }^{10}$ Aliman Saragih, "Kontribusi Al Jam'iyatul Washliyah terhadap Kemerdekaan Indonesia (1930-1950)," dalam MIQOT: Jurnal Ilmu-ilmu Keislaman, Vol. 40, No. 1, 2016.

${ }^{11}$ Tentang Muhammadiyah bisa dilihat dalam Masdar Hilmy, "Quo-Vadis Islam Moderat Indonesia? Menimbang Kembali Modernisme Nahdlatul Ulama dan Muhammadiyah," dalam MIQOT: Jurnal Ilmu-ilmu Keislaman, Vol. 36, No. 2, 2012.

${ }^{12}$ Dja'far Siddik dan Ja'far, Al-Ittihadiyah: Delapan Dasawarsa Menerangi Nusantara (Medan: Perdana Publishing, 2017).

${ }^{13}$ Salamuddin, "Teologi Rasional Pada Pesantren Tradisional: Telaah Konsep Teologi pada Buku Daras Teologi di Pesantren Musthafawiyah," dalam MIQOT: Jurnal Ilmu-ilmu Keislaman, Vol. 38, No. 1, 2014, pp. 45-62. 
${ }^{14}$ Sebagian besar tokoh Cina adalah penentang Republik. Pada bulan Juli 1947, Laskar Cina (Poh An Tui) bergabung dengan Pasukan Belanda untuk menduduki Sumatera Timur, dan pada akhir tahun 1947 ikut mempersiapkan berdirinya Negara Sumatera Timur (NST) yang disponsori oleh Belanda dan kaum bangsawan Melayu. Gerakan NST merupakan aliansi anti Republik yang paling luas. Gerakan ini memiliki persekutuan oposisi yang terdiri atas kaum bangsawan Melayu, sebagian besar Rajaraja Simalungun, beberapa Kepala Suku Karo, dan kebanyakan tokoh-tokoh Cina. Lihat Michael van Langenberg, "Sumatera Timur: Mewadahi Bangsa Indonesia dalam Sebuah Keresidenan di Sumatera," dalam Audrey R. Kahin (ed.). Pergolakan Daerah pada Awal Kemerdekaan (Jakarta: Grafiti Pers, 1990), h. 139-140.

${ }^{15}$ Setelah terbentuknya NKRI 17 Agustus 1950, perjalanan sejarah berubah lagi. Perjuangan pembebasan Irian Barat mendorong pemerintah mendapatkan dukungan dari blok Komunis. Akibatnya, PKI diizinkan lagi mengadakan aktivitas politiknya, sehingga strategi kepartaian umat Islam berubah dan partai politik perlu diperbanyak agar suara bertambah. Latar belakang politik yang demikian ini salah satu sebab mengapa NU menyatakan keluar dari Masyumi pada muktamarnya di Palembang tahun 1952. Lihat artikel “Apa, Sesudah NU Balik Kanan ke Khittah 1926,” Suara Pembaruan, 5 Maret 1988,

${ }^{16} \mathrm{Niam}$ menilai bahwa NU telah melahirkan banyak ulama dan intelektual Muslim, lihat Khoirun Niam, "Nahdlatul Ulama and the Production of Muslim Intellectuals in the Beginning of 21st Century Indonesia," dalam Journal of Indonesian Islam, Vol. 11, No. 2, 2017, pp. 351-388.

${ }^{17}$ Pendiri organisasi Al Jam'iyatul Washliyah diantaranya Haji M. Arsyad Thalib Lubis adalah adik kandung Haji Baharuddin Thalib Lubis yang termasuk pendiri Nahdatul Ulama (NU) tahun 1947 di Padangsidempuan dan menjadi Ketua Pimpinan Wilayah NU dari tahun 1947 sampai 1956. Namun pada Konferensi Wilayah III tahun 1956 ia sudah 'uzur karena ketuaan, maka tidak lagi aktif sebagai pengurus wilayah.

${ }^{18}$ Menurut informasi, tokoh-tokoh Melayu yang masuk dalam kepengurusan NU Wilayah Sumatera Utara ini sebagian terlibat dalam gerakan pendirian Negara Sumatera Timur (NST), dan untuk menyelamatkan dan mengembalikan mereka kembali ke dalam NKRI, sebahagian mereka masuk dalam organisasi Nahdlatul Ulama. Ternyata upaya mereka tersebut dari sudut politis, cukup berhasil.

${ }^{19}$ Di kawasan perkotaan di Sumatera Timur, seperti Medan, Pematang Siantar, Tebing Tinggi, Tanjung Balai dan Binjai sejak abad ke-19 sampai awal abad ke-20 telah banyak terdapat migran etnis Mandailing. Mereka mendirikan perkampungan dan pemukiman etnis, seperti terdapat nama-nama kampung Mandailing, juga pekuburan Mandailing. Sebutan Mandailing dijadikan sebagai identitas agama Islam oleh masyarakat, yaitu untuk membedakannya dengan etnis Batak yang beragama Kristen.

${ }^{20}$ Gugatan terhadap kepemimpinan NU wilayah Sumatera Utara digerakkan oleh beberapa tokoh seperti Marah Halim Siregar, yang pada waktu itu menjabat Ketua GP Ansor Sumatera Utara. Setelah terjadi fusi tahun 1973 dan sampai 1980an terus berlanjut, eksistensi kepemimpinan NU Sumatera Utara tidak jelas. Berulangkali dilakukan pertemuan dan konferensi dadakan di luar prosedur organisasi ternyata 
tidak bisa mencari solusi yang tepat. Wawancara dengan Basyar Harahap, 11 Desember 2005.

${ }^{21}$ Greg Barton dan Andrée Feillard, "Nahdlatul Ulama, Abdurrahman Wahid and Reformation: What Does NU's November 1997 National Gathering Tell Us?," dalam Studia Islamika, Vol. 6, No. 1, 1999, pp. 1-39.

${ }^{22}$ Ali Munhanif, "The Khittah of 1926 Reexamined: Views of the NU in PostCipasung Congress," dalam Studia Islamika, Vol. 3, No. 1996, pp. 85-199; Robin Bush, "Redefining "Political Islam" in Indonesia: Nahdlatul Ulama and Khittah '26," dalam Studia Islamika, Vol. 7, No. 2, 2000, pp. 59-86.

${ }^{23}$ Pada saat pengurus NU wilayah Sumatera Utara dipimpin Marah Halim Siregar tahun 1982-an, terjadi penjualan aset-aset NU dengan mempergunakan atas nama organisasi. Hal ini memberikan pengaruh yang besar terhadap eksistensi NU sebagai organisasi Islam dari kalangan umat Islam, juga di kalangan internal NU sendiri. Dalam kepengurusan NU di tingkat wilayah dan tingkat cabang, juga terlihat pengkotakan antar daerah, terutama upaya untuk meminggirkan orang Mandailing yang notabenenya lulusan Pesantren Musthafawiyah. Akibatnya, banyak lulusan pesantren ini beralih ke organisasi Al Washliyah atau memposisikan dirinya sebagai NU kultural. Kepercayaan dari pihak luar dan internal terhadap NU kembali muncul setelah NU Sumatera Utara dipimpin oleh H. Baharuddin Lubis, S.H. tahun 1990-1994. Wawancara dengan H. Imron Hasibuan, 10 Desember 2005.

${ }^{24}$ Sebelum tahun 1971-an, di wilayah Sumatera Utara banyak terdapat sekolah atau madrasah dengan memakai nama organisasi NU. Setelah pemerintah mendirikan GUPPI tahun 1971 dan langsung di bawah asuhan Golkar, perguruan NU banyak diganti dengan nama GUPPI, dan memang para pengasuh perguruan ini umumnya adalah warga NU sendiri. Akibat dari perubahan nama tersebut, lembaga perguruan NU menjadi hilang. Hal ini ditopang pula dengan tidak aktifnya lembaga Ma'arif yang mengelola pendidikan di dalam struktur kepengurusan NU.

${ }^{25}$ Sebenarnya Hasan Basri Batubara pada mulanya adalah termasuk kader yang dibina oleh H.M. Nuddin Lubis, dan ia aktif selama kampanye Pemilu 1971 untuk Partai NU, dan sebelum Pemilu dilaksanakan, ia sempat ditahan oleh pihak berwajib dan ia memilih di dalam penjara. Demikian pula, pada saat Muktamar NU di Surabaya tahun 1971, ia masih bersama-sama H.M. Nuddin Lubis membangun NU di Sumatera Utara. Wawancara dengan Hasan Basri Hasibuan dan Basyar Harahap, 12 Desember 2005.

${ }^{26}$ Jika dilihat dari latar sejarah berdirinya NU di Sumatera Utara tahun 1947 di Padangsidempuan, yang muncul sebagai pendirinya adalah para lulusan pesantren Musthafawiyah atas inisiatif dari Syekh Musthafa Husein. Di antara lulusan Musthafawiyah tersebut adalah H.M. Nuddin Lubis, Aminuddin Aziz, Sai Aman Nasution, Syekh Ja'far Abdul Wahab, Haji Ismail Sulaiman, dan Syekh Ali Hasan Ahmad ad-Dary. Hal ini dapat dilihat pada susunan pengurus NU wilayah Sumatera Utara sejak berdiri pada tahun 1947 sampai Konferensi Ketujuh di Prapat pada tahun 1969. 